\title{
Bleeding manifestations in a patient with amyloidosis
}

\author{
Luai Alhazmi, ${ }^{1}$ Abdulelah Nuqali, ${ }^{2}$ Ragheb Assaly ${ }^{1}$
}

${ }^{1}$ The University of Toledo Medical Center, Toledo, Ohio, USA

${ }^{2}$ The George Washington University, Washington, DC, USA

\section{Correspondence to} Dr Abdulelah Nuqali, abdulelah.n@gmail.com

Accepted 27 September 2016

\section{DESCRIPTION}

A woman aged 67 years with a history of multiple myeloma who was receiving chemotherapy was admitted to the medical intensive care unit with massive gastrointestinal bleeding. She denied having any family history of bleeding diathesis. Her laboratory studies showed a normal platelet count and coagulation profile, whereas her serum-free lambda light chain level was elevated at $183.25 \mathrm{mg} / \mathrm{dL}$ (reference: 0.57-2.63).

She underwent gastric endoscopy that showed a distal gastric body mass of $3 \times 7 \mathrm{~cm}$ on the greater curvature with an adjacent collection of submucosal hematoma (figure 1). Biopsy samples were obtained from the mass that showed an abnormally thickened blood vessel with amyloid-like material in the wall (figure 2). The patient had also had a colon biopsy 5 years earlier, which showed amorphous Congo red-positive deposits in the vessel walls.

Two days following repeated bouts of haematemesis and retching, she developed right periorbital, atraumatic, non-blanching ecchymosis. No further skin bruises were observed (figure 3).

The bleeding manifestations frequently observed in patients with immunoglobulin light-chain amyloidosis have been attributed to different pathogenic factors, including amyloid deposits in capillary walls, factor $\mathrm{X}$ deficiency and the presence of plasma components interfering with fibrin formation. However, bleeding in most patients occurs in the absence of abnormal clotting test results, suggesting that haemorrhage in amyloidosis is most often due to amyloid infiltration of blood vessels. ${ }^{1}$

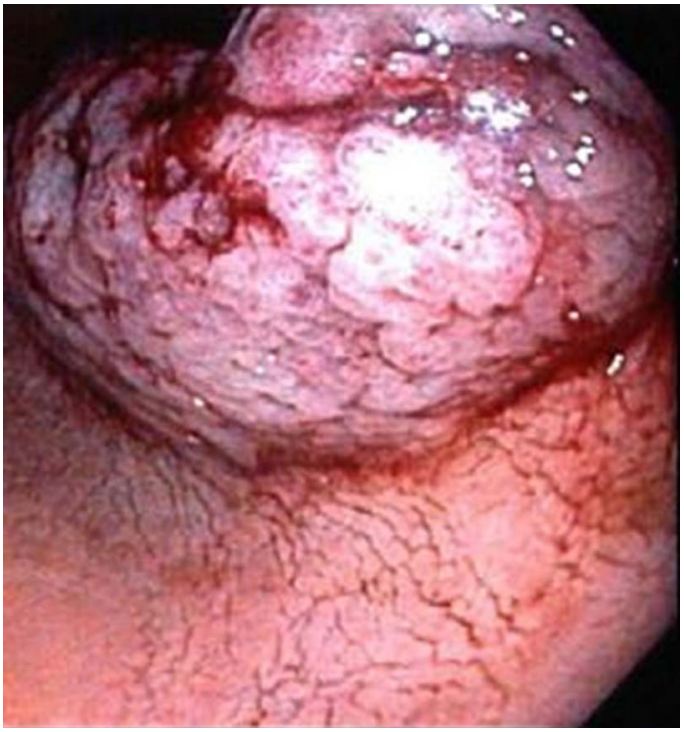

Figure 1 Gastric endoscopy shows a distal gastric body mass of $3 \times 7 \mathrm{~cm}$ on the greater curvature.

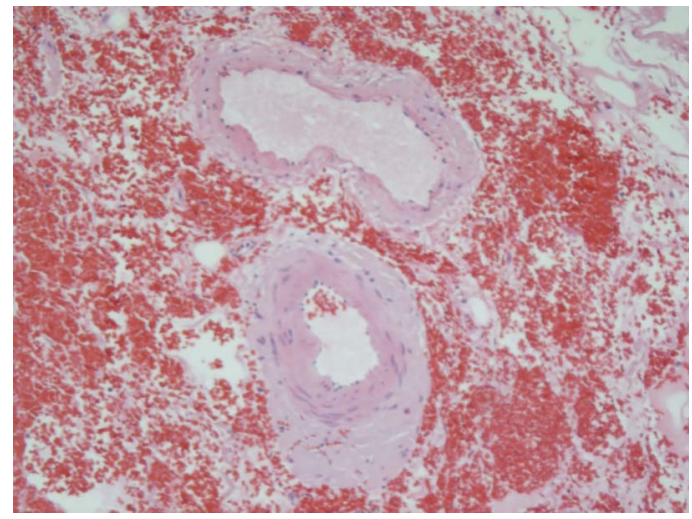

Figure 2 Photomicrograph of histological section of gastric submucosal haematoma biopsy sample shows abnormally thickened blood vessels with amyloid-like material in the wall ( $\times 10$ magnification).

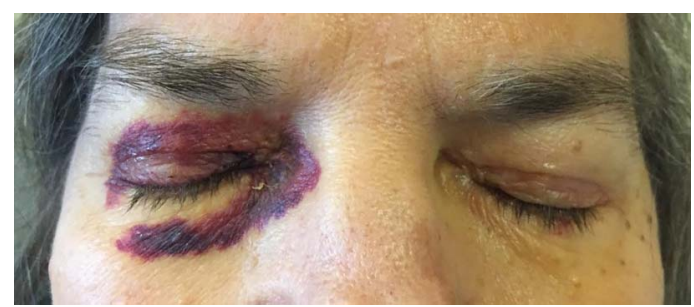

Figure 3 Right periorbital ecchymosis.

Skin bleeding in these patients is called amyloid purpura. Classically, it occurs in the periorbital region either spontaneously or after strenuous coughing or vomiting. ${ }^{2}$

\section{Learning points}

- Amyloidosis may cause vascular fragility and therefore increases bleeding tendency.

- Periorbital cutaneous bleeding in these patients is called amyloid purpura.

Competing interests None declared.

Patient consent Obtained.

Provenance and peer review Not commissioned; externally peer reviewed.

\section{REFERENCES}

1 Yood RA, Skinner M, Rubinow A, et al. Bleeding manifestations in 100 patients with amyloidosis. JAMA 1983;249:1322-4.

2 Merlini G, Wechalekar AD, Palladini G. Systemic light chain amyloidosis: an update for treating physicians. Blood 2013;121:5124-30. 
Copyright 2016 BMJ Publishing Group. All rights reserved. For permission to reuse any of this content visit http://group.bmj.com/group/rights-licensing/permissions.

BMJ Case Report Fellows may re-use this article for personal use and teaching without any further permission.

Become a Fellow of BMJ Case Reports today and you can:

- Submit as many cases as you like

- Enjoy fast sympathetic peer review and rapid publication of accepted articles

- Access all the published articles

- Re-use any of the published material for personal use and teaching without further permission

For information on Institutional Fellowships contact consortiasales@bmjgroup.com

Visit casereports.bmj.com for more articles like this and to become a Fellow 